\title{
Graded Levels of NPK and Organic Sources of Nutrients on Productivity and Profitability of Fodder Maize
}

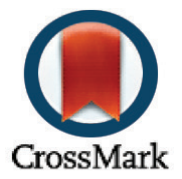

\section{S. R. Vinod Kumar, K. Suseendran, P. Stalin, S. Jawahar, K. Arivukkarasu}

Department of Agronomy, Faculty of Agriculture, Annamalai University, Chidambaram, Tamil Nadu, India

\begin{abstract}
Field experiments were conducted at farmer's field in C. Mutlur Village of Chidambaram Block during Navarai and Samba season of 2010 to study the effect of graded levels of NPK and organic sources of nutrients on productivity and profitability of fodder maize. The experiments were conducted in randomized block design and replicated thrice with seven treatments, namely $\mathrm{T}_{1-} 100 \%$ Recommended dose fertilizers (RDF), $\mathrm{T}_{2}-75 \% \mathrm{RDF}+$ Vermiwash at $4 \%$ on 15 and 25 DAS, $\mathrm{T}_{3}-50 \%$ RDF, $\mathrm{T}_{4}-75 \% \mathrm{RDF}+$ soil application of humic acid at $0.2 \%\left(125 \mathrm{~g} \mathrm{ha}^{-1}\right), \mathrm{T}_{5}-50 \%$ $\mathrm{RDF}+$ Humic acid at $0.2 \%, \mathrm{~T}_{6}-75 \% \mathrm{RDF}+$ Panchagavya at $3 \%$ on 15 and $25 \mathrm{DAS}$, and $\mathrm{T}_{7}-$ $50 \% \mathrm{RDF}+$ Panchagavya at $3 \%$ on 15 and 25 DAS. The growth attributes, namely plant height, leaf area index, and dry matter production of fodder maize, were favorably influenced by soil application of 75\% RDF + soil application of humic acid at $0.2 \%\left(\mathrm{~T}_{4}\right)$ and recorded the highest fodder yield of 25.56 and 24.89 t/ha during Navarai 2010 and Samba 2010, respectively. It was followed by $50 \%$ of RDF + humic acid $\left(\mathrm{T}_{5}\right)$. The same treatment registered its superiority over others on the economics of fodder maize and recorded higher return per rupee invested of Rs. 1.41 and 1.39 during Navarai and Samba season, respectively. Therefore, it can be concluded that conjoint application of $75 \% \mathrm{RDF}+$ humic acid at $0.2 \%$ holds immense potentiality to boost the productivity and profitability of fodder maize.
\end{abstract}

Address for

correspondence:

S. R. Vinod Kumar,

Department of Agronomy,

Faculty of Agriculture,

Annamalai University,

Chidambaram, Tamil Nadu,

India.

E-mail: vinodagronomy@

rediffmail.com

Keywords:

Economics, Fodder maize, Growth, NPK levels,

Organics, Yield

Received: 08 ${ }^{\text {th }}$ March 2019

Accepted: $09^{\text {th }}$ March 2019

Published: $21^{\text {rd }}$ March 2019

\section{INTRODUCTION}

Livestock plays an important role in Indian economy. About 20.5 million people depend upon livestock for their livelihood. India has vast livestock resources. Livestock sector contributes $4.11 \%$ GDP and $25.6 \%$ of total agriculture GDP. Instead, we are suffering from perpetual shortage of milk, meat, and wool. The major reason for the low production of livestock products is the shortage of fodder. The estimated requirement of fodder is being 822 M.T. as against the availability of 488 M.T. ${ }^{[1]}$ In India, it is estimated that only about $4.4 \%$ cultivated area is under fodder cultivation, while in Tamil Nadu, fodder crops occupy about $8.6 \mathrm{~L}$ ha. It may not be possible to increase the area under fodder crops due to ever-increasing pressure on available foodgrains and commercial crops. Hence, the only alternative to meet fodder requirement is to increase the yield of fodder per unit area per unit time. This can be achieved by growing high-yielding varieties of cereal fodders and forage legumes and by studying the appropriate nutritional dose to the fodder crops.

Among the cultivated non-legume fodder, maize is the most important crop which can be grown around the year under irrigated condition. Maize is a quick growing and high-yielding crop inhabitant with no hazard of prussic acid poisoning and is considered as a valuable fodder crop. Fodder maize is highly relished by cattle as it is rich in protein, carbohydrate, minerals, and vitamins. The role of humic substances, namely vermiwash and panchagavya (especially, humic acid an important constituent of organic matter), on the transformation and availability of $\mathrm{N}$ in soil is found to be an unexploited area. Therefore, it is imperative to study the role of organic substances (humic acid) on the transformation and availability of nitrogen as well as on the performance of fodder maize and high yield of fodders.

Earthworm secretions have found to be the beneficial effect on crop growth with the presence of various nutrients in considerable quantities. Panchagavya is a combination of five products obtained from cow which is used in traditional medicines extensively. Natarajan revealed that, among the plant growth stimulants defined in Vrkshayurveda, panchagavya was found to be the best in enhancing the biological efficiency of crop plants and the quality of fruits and vegetables. ${ }^{[2]}$ Higher nutrient uptake and more use efficiency in both main and ratoon crops of annual moringa 
were observed with the application of panchagavya. Cow's curd is rich in microbes (lactobacillus) that are responsible for fermentation. ${ }^{[3]}$ Foliar spray of coconut water as growth hormone increased the biomass and yield in sweet pepper by $200 \%$ over control. ${ }^{[4]}$ Reddy and Singh observed that cow's urine (gomootra) was rich in urea and acted both as nutrients and hormones. ${ }^{[5]}$ Keeping the above-said facts in consideration, field experiments were conducted to study the effect of graded levels of NPK and organic sources of nutrients on productivity and profitability of fodder maize.

\section{MATERIALS AND METHODS}

Field experiment was conducted in the farmer's field at C. Mutlur village of Chidambaram block in Cuddalore district during Navarai and Samba seasons of 2010 to study the effect of graded levels of NPK and organics on productivity and profitability of fodder maize. The soil is moderately drained clay loamy in texture with low in available nitrogen (210.27 kg/ha), medium in available $\mathrm{P}_{2} \mathrm{O}_{5}(17.95 \mathrm{~kg} / \mathrm{ha})$, and high in available $\mathrm{K}_{2} \mathrm{O}(320.07 \mathrm{~kg} / \mathrm{ha})$. The experimental field was ploughed with tractor drawn cultivator in a criss-cross manner. The seeds were sown on January 7, 2010 (Navarai), and July 9, 2010 (Samba), by adopting the spacing of $30 \times$ $15 \mathrm{~cm}$. The experiments were conducted in randomized block design and replicated thrice with seven treatments, namely $\mathrm{T}_{1}$ $-100 \%$ recommended dose fertilizers (RDF), $\mathrm{T}_{2}-75 \% \mathrm{RDF}+$ vermiwash at $4 \%$ on 15 and 25 DAS, $\mathrm{T}_{3}-50 \% \mathrm{RDF}, \mathrm{T}_{4}-75 \%$ $\mathrm{RDF}+$ soil application of humic acid at $0.2 \%, \mathrm{~T}_{5}-50 \% \mathrm{RDF}$ + humic acid at $0.2 \%, \mathrm{~T}_{6}-75 \% \mathrm{RDF}+$ panchagavya at $3 \%$ on 15 and $25 \mathrm{DAS}$, and $\mathrm{T}_{7}-50 \% \mathrm{RDF}+$ panchagavya at $3 \%$ on 15 and 25 DAS. The RDF of 60:40:40 kg NPK ha-1 was applied to control plots, and the rest of the plots was fertilized as per the treatment schedule. Need-based plant protection measures were taken up based on economic threshold level of pest and diseases.

\section{Preparation of vermiwash solution}

Different layers of the bed around 25 worms of Perionyx excavate (native species) and another 25 worms of Eudrilus eugeniae (African species) were introduced in prepared container. On the $16^{\text {th }}$ day, the tap was closed, and on top of the unit, a $5 \mathrm{~L}$ vessel perforated at the base like a sprinkler was gradually allowed to sprinkle on it. The water slowly percolated through the compost and drilospheres, carrying with it nutrients from freshly formed castings, as well as washings from the drilospheres through the filter unit. The washings were collected and used as a foliar spray. The vermiwash was clear and transparent pale yellow in color liquid with the $\mathrm{pH}$ of 6.83 . Vermiwash at $4 \%$ was applied as per the treatment schedule on 15 and 25 DAS.

\section{Humic acid}

Humic acid of $2 \%$ concentration was obtained from the research wing of Neyveli Lignite Corporation for the experiment. From this, $0.2 \%$ concentration was prepared and used for soil application. Humic acid at $125 \mathrm{~g} /$ ha was applied for soil application as per treatment schedule on 15 and 25 DAS.

\section{Preparation of panchagavya}

Improved Panchagavya was prepared using the following ingredients: Cow dung (5 kg), cow's urine (3 L), cow's milk (3 L), cow's curd (2 L), and cow's ghee (1 L). Panchagavya at $3 \%$ was applied as per treatment schedule on 15 and 25 DAS.

The biometric observations were taken at critical stages of the crop. The gross return per ha for each treatment was worked out based on the present market rate. The net income was calculated by subtracting the cost of cultivation from the gross income. The BCR was calculated treatment wise by dividing the gross income by cost of cultivation.

\section{RESULTS AND DISCUSSIONS}

\section{Growth attributes}

All the growth components, namely plant height, leaf area index, and dry matter production, were significantly influenced by soil application of humic acid at $125 \mathrm{~g} /$ ha along with $75 \%$ of RDF (45: 30: $30 \mathrm{~kg} / \mathrm{ha}$ NPK) $\mathrm{T}_{4}$. Taller plants under $\mathrm{T}_{4}$ might be due to the soil application of humic acid. Application of $75 \%$ of recommended fertilizer dose + soil application of humic acid $\left(\mathrm{T}_{4}\right)$ increased the plant height due to an increase in protein synthesis and cell growth [Table 1]. The results of the present study are in line with the findings

Table 1: Effect of graded levels of NPK and organic sources of nutrients on plant height $(\mathrm{cm})$ of fodder maize

\begin{tabular}{|c|c|c|c|c|c|c|}
\hline \multirow[t]{3}{*}{ Treatments } & \multicolumn{6}{|c|}{ Plant height (cm) } \\
\hline & \multicolumn{2}{|c|}{20 DAS } & \multicolumn{2}{|c|}{40 DAS } & \multicolumn{2}{|c|}{ At harvest } \\
\hline & Navarai 2010 & Samba 2010 & Navarai 2010 & Samba 2010 & Navarai 2010 & Samba 2010 \\
\hline $\mathrm{T}_{1}$ & 52.62 & 51.09 & 109.14 & 108.85 & 134.08 & 132.87 \\
\hline $\mathrm{T}_{2}$ & 67.55 & 63.55 & 136.09 & 134.69 & 164.01 & 164.90 \\
\hline $\mathrm{T}_{3}$ & 57.21 & 54.30 & 120.15 & 118.87 & 141.24 & 142.89 \\
\hline $\mathrm{T}_{4}$ & 75.64 & 74.03 & 149.19 & 147.75 & 183.66 & 182.07 \\
\hline $\mathrm{T}_{5}$ & 71.83 & 70.58 & 142.74 & 141.50 & 172.96 & 173.36 \\
\hline $\mathrm{T}_{6}$ & 64.73 & 60.75 & 131.24 & 131.37 & 157.15 & 159.01 \\
\hline $\mathrm{T}_{7}$ & 61.28 & 57.49 & 127.25 & 124.88 & 149.13 & 151.08 \\
\hline S.Ed & 1.59 & 1.52 & 2.85 & 2.66 & 3.5 & 3.39 \\
\hline $\mathrm{CD}(P=0.05)$ & 3.28 & 3.14 & 5.70 & 5.50 & 7.09 & 7.01 \\
\hline
\end{tabular}


Table 2: Effect of graded levels of NPK and organic sources of nutrients on leaf area index of fodder maize

\begin{tabular}{|c|c|c|c|c|c|c|}
\hline \multirow[t]{3}{*}{ Treatments } & \multicolumn{6}{|c|}{ Leaf area index } \\
\hline & \multicolumn{2}{|c|}{20 DAS } & \multicolumn{2}{|c|}{40 DAS } & \multicolumn{2}{|c|}{ At harvest } \\
\hline & Navarai 2010 & Samba 2010 & Navarai 2010 & Samba 2010 & Navarai 2010 & Samba 2010 \\
\hline $\mathrm{T}_{1}$ & 2.19 & 2.18 & 4.15 & 4.13 & 4.19 & 4.30 \\
\hline $\mathrm{T}_{2}$ & 2.46 & 2.43 & 5.05 & 5.02 & 5.63 & 5.53 \\
\hline $\mathrm{T}_{3}$ & 2.27 & 2.26 & 4.40 & 4.36 & 4.60 & 4.64 \\
\hline $\mathrm{T}_{4}$ & 2.73 & 2.65 & 5.82 & 5.64 & 6.69 & 6.50 \\
\hline $\mathrm{T}_{5}$ & 2.56 & 2.51 & 5.57 & 5.40 & 6.35 & 6.14 \\
\hline $\mathrm{T}_{6}$ & 2.43 & 2.40 & 4.84 & 4.91 & 5.34 & 5.39 \\
\hline $\mathrm{T}_{7}$ & 2.35 & 2.33 & 4.56 & 4.63 & 4.95 & 5.02 \\
\hline S.Ed & 0.03 & 0.02 & 0.10 & 0.10 & 0.16 & 0.14 \\
\hline $\mathrm{CD}(P=0.05)$ & 0.07 & 0.06 & 0.22 & 0.21 & 0.33 & 0.30 \\
\hline
\end{tabular}

Table 3: Effect of graded levels of NPK and organic sources of nutrients on dry matter production (kg/ha) of fodder maize

\begin{tabular}{|c|c|c|c|c|c|c|}
\hline \multirow[t]{3}{*}{ Treatments } & \multicolumn{6}{|c|}{ Dry matter production (kg/ha) } \\
\hline & \multicolumn{2}{|c|}{20 DAS } & \multicolumn{2}{|c|}{40 DAS } & \multicolumn{2}{|c|}{ At harvest } \\
\hline & Navarai 2010 & Samba 2010 & Navarai 2010 & Samba 2010 & Navarai 2010 & Samba 2010 \\
\hline $\mathrm{T}_{1}$ & 2537.44 & 2523.85 & 3131.66 & 3072.76 & 3615.40 & 3615.02 \\
\hline $\mathrm{T}_{2}$ & 3278.13 & 3156.93 & 4099.28 & 3934.71 & 4729.94 & 4629.08 \\
\hline $\mathrm{T}_{3}$ & 2699.61 & 2682.46 & 3378.49 & 3296.75 & 3969.80 & 3878.53 \\
\hline $\mathrm{T}_{4}$ & 3625.13 & 3578.36 & 4810.70 & 4608.08 & 5550.81 & 5421.28 \\
\hline $\mathrm{T}_{5}$ & 3463.13 & 3417.71 & 4570.41 & 4382.275 & 5274.81 & 5156.18 \\
\hline $\mathrm{T}_{6}$ & 3129.90 & 3010.58 & 3877.99 & 3744.47 & 4515.84 & 4405.27 \\
\hline $\mathrm{T}_{7}$ & 2861.48 & 2840.18 & 3627.17 & 3519.52 & 4242.89 & 4140.62 \\
\hline S.Ed & 75.35 & 73.06 & 116.32 & 106.36 & 133.18 & 125.13 \\
\hline $\mathrm{CD}(P=0.05)$ & 155.38 & 150.66 & 239.86 & 219.33 & 274.63 & 258.03 \\
\hline
\end{tabular}

of Balasubramanian et al. in rice. ${ }^{[6]} \mathrm{LAI}$, the good measure of plant growth, was also found to be higher in both the seasons with the application of $75 \%$ of RDF + soil application of humic acid $\left(\mathrm{T}_{4}\right)$ [Table 2]. Humic acid might have enhanced the LAI which produced bigger leaves as experienced by Mandal et al. in rice. ${ }^{[7]}$ Dry matter production also followed a similar trend as LAI in the fodder maize [Table 3]. Moreover, the presence of numerous active enzymes in humic acid might have contributed to the increased $\mathrm{DMP}^{[8]}$ The results are in agreement with the findings of Hasegawa and Jinya Yazaki, 1987, in rice. ${ }^{[9]}$ Application of recommended fertilizer dose and soil application of humic acid helped in enhancing the growth and development of the crop. Similar results were reported by Sharma, 2009, in fodder maize. ${ }^{[1]}$ Least values of growth attributes of fodder maize recorded under the recommended fertilizer dose of NPK $\left(\mathrm{T}_{1}\right)$ were noticed due to the inadequate supply of nutrients to the crop.

\section{Yield}

The yield of fodder maize was significantly influenced by the application of $75 \%$ of recommended fertilizer dose + soil application of humic acid $\left(\mathrm{T}_{4}\right)$ [Table 4]. Higher fodder yield was produced fewer than $75 \%$ of RDF + soil application of humic acid $\left(\mathrm{T}_{4}\right)$ in both the season and thus proved its
Table 4: Effect of graded levels of NPK and organic sources of nutrients on green fodder yield ( $\mathrm{t} / \mathrm{ha}$ ) of Maize

\begin{tabular}{lcc}
\hline Treatments & Navarai 2010 & Samba 2010 \\
\hline $\mathrm{T}_{1}$ & 19.74 & 19.24 \\
$\mathrm{~T}_{2}$ & 23.84 & 23.19 \\
$\mathrm{~T}_{3}$ & 21.59 & 21.14 \\
$\mathrm{~T}_{4}$ & 25.56 & 24.89 \\
$\mathrm{~T}_{5}$ & 24.69 & 24.01 \\
$\mathrm{~T}_{6}$ & 23.69 & 22.85 \\
$\mathrm{~T}_{7}$ & 22.47 & 21.97 \\
$\mathrm{~S} E d$ & 0.39 & 0.38 \\
$\mathrm{CD}(P=0.05)$ & 0.81 & 0.79 \\
\hline
\end{tabular}

concurrent influence on fodder maize yield through the enhancement of yield attributes. This might be due to an adequate supply of nutrients at different growth stages of the crop as well as the presence of growth regulators in humic acid contributing to higher fodder yield. Mazumdar stated the nitro humic acids increased the fodder yield. ${ }^{[10]}$

The least fodder yield under recommended dose of 
Table 5: Effect of graded levels of NPK and organic sources of nutrients on economics of fodder maize

\begin{tabular}{|c|c|c|c|c|c|c|c|c|}
\hline \multirow[t]{2}{*}{ Treatments } & \multicolumn{2}{|c|}{$\begin{array}{c}\text { Cost of cultivation } \\
\left.\text { (Rs. ha- } \mathbf{h}^{-1}\right)\end{array}$} & \multicolumn{2}{|c|}{$\begin{array}{l}\text { Gross returns } \\
\left(\text { Rs. ha } \text { h }^{-1}\right)\end{array}$} & \multicolumn{2}{|c|}{$\begin{array}{l}\text { Net income } \\
\left(\text { Rs. ha } \mathbf{A}^{-1}\right)\end{array}$} & \multicolumn{2}{|c|}{$\begin{array}{c}\text { Return rupee }^{-1} \\
\text { invested }\end{array}$} \\
\hline & $\begin{array}{l}\text { Navarai } \\
2010\end{array}$ & $\begin{array}{l}\text { Samba } \\
2010\end{array}$ & $\begin{array}{l}\text { Navarai } \\
2010\end{array}$ & $\begin{array}{l}\text { Navarai } \\
2010\end{array}$ & $\begin{array}{c}\text { Samba } \\
2010\end{array}$ & $\begin{array}{c}\text { Samba } \\
2010\end{array}$ & $\begin{array}{l}\text { Navarai } \\
2010\end{array}$ & $\begin{array}{c}\text { Samba } \\
2010\end{array}$ \\
\hline $\mathrm{T}_{1}$ & 17500.67 & 17426.52 & 19740 & 19240.00 & 2289.33 & 1813.48 & 1.13 & 1.10 \\
\hline $\mathrm{T}_{2}$ & 17777.78 & 177562.8 & 23840 & 23190.00 & 6062.22 & 5433.20 & 1.36 & 1.30 \\
\hline $\mathrm{T}_{3}$ & 17585.90 & 17502.87 & 21590 & 21140.00 & 4004.10 & 3637.13 & 1.23 & 1.21 \\
\hline $\mathrm{T}_{4}$ & 18005.00 & 17920.00 & 25560 & 24890.00 & 7555.00 & 6970.00 & 1.41 & 1.39 \\
\hline $\mathrm{T}_{5}$ & 17888.89 & 178372.86 & 24690 & 24010.00 & 6801.11 & 6172.14 & 1.38 & 1.34 \\
\hline $\mathrm{T}_{6}$ & 17767.68 & 17672.59 & 23690 & 22850.00 & 5922.32 & 5177.41 & 1.33 & 1.29 \\
\hline $\mathrm{T}_{7}$ & 17768.06 & 17588.07 & 22470 & 21970.00 & 4801.94 & 4381.93 & 1.27 & 1.25 \\
\hline
\end{tabular}

NPK $\left(T_{1}\right)$ alone might be due to the lack of adequate supply of phosphorous and nitrogen to the crop which, in turn, affected the growth and yield components of the crop ultimately reflecting yield. The present result is in agreement with the earlier findings of Tomar et al. ${ }^{[11]}$ in gram, Trivedi in blackgram, ${ }^{[12]}$ Singh et al. ${ }^{[13]}$ in pigeon pea, Gracy Mathew et al. ${ }^{[14]}$ in rainfed upland cowpea, and Pandian et al. in rice fallow green gram. ${ }^{[15]}$

\section{Economics}

Among the treatments, $75 \%$ of $\mathrm{RDF}+$ soil application of humic acid $\left(\mathrm{T}_{4}\right)$ recorded the highest gross income, net income, and return per rupee invested in fodder maize [Table 5]. The least gross income was registered under the treatment recommended dose of $\mathrm{NPK}\left(\mathrm{T}_{1}\right)$ alone due to reduction in fodder yield of fodder maize. The highest net return per rupee invested was obtained with $75 \%$ of RDF + soil application of humic acid $\left(\mathrm{T}_{4}\right)$, namely Rs. 1.41 and 1.39, during Navarai 2010 and Samba 2010, respectively. Higher net return might be due to the beneficial effects of $75 \%$ of RDF + soil application of humic acid favouring better growth and yield components and yield of crop which ultimately resulted in higher return per rupee invested.

\section{CONCLUSION}

Based on the results of experiments carried out at C. Mutlur farmer's field, it can be concluded that application of $75 \%$ of recommended fertilizer dose + humic acid holds promise to boost the productivity and profitability of fodder maize. Thus, it is agronomically feasible and economically viable technology which paves way for higher return per rupee invested in fodder maize.

\section{REFERENCES}

1. Sharma KC. Integrated nitrogen management in fodder oats (Avena sativa) in hot arid ecosystem of Rajasthan. Indian J Agron 2009; 54:459-64.

2. Natarajan K. Panchagavya: A Manual. Mapusa, Goa, India: Other India Press; 2002. p. 33.

3. Chandha M. Butter milk as plant growth promoter, honey bee. Soil Sci Plant Nutr 1996;34:147.
4. Mamaril JC, Lopez AM. The effect of coconut water growth hormones (CWGH) on the growth, development and yield of sweet pepper. Philipp J Coconut Stud 1997;222:18.

5. ReddyNS, SinghR.Effectofnitrogenandphosphorousongrowthand yield of French bean (Phaseolus vulgaris). Indian J Agron 1998;43: 367-70.

6. Balasubramanian P, Chandrasekaran S, Govindasamy R. Effects of Lignite Humic Acids on the Growth and Changes in Phenolics of Rice Seedlings (Oryza sativa L.) var. IR 50. Proceedings of the National Seminar on Humus Acids in Agric. Annamalai Nagar, Chidambaram: Annamalai University; 1989. p. 201-7.

7. Mandal BK, Chatterjee P, Bhattacharya SP. Effect of humic acid on wet season rice. IRRN 1989;14:18-9.

8. Schnitzer M, Khan SU. Humic Substances in the Environment. New York: Marcel Dekker Inc.; 1991.

9. Hasegawa I, Yazaki J. Effect of humic acid on the growth of rice substances and the physiological activity of roots. Coll Agric Vet Med Nihon Univ 1987;58:633-7.

10. Mazumdar BK. Status and prospect of coal and coal acids. Fuel Sci Tech 1982;1:3-14.

11. Tomar RK, Namdeo KN, Raghu JS. Efficacy of phosphate solubilising bacteria biofertilizer with phosphorous on growth and yield of gram (Cicer arietinum). Indian J Agron 1996;41:412-5.

12. Trivedi SK. Response of blackgram to nitrogen, phosphorous and sulphur. Legume Res 1996;19:7-9

13. Singh GV, Rana NS, Ahlawat IP. Effect of nitrogen, Rhizobium inoculation and phosphorous on growth and yield of pigeon pea (Cajanus cajan). Indian J Agron 1998;43:358-61.

14. Mathew G, Sreenivasan C, Anilkumar K. Effect of phosphorous and sulphur on growth, yield and nutrient uptake of rainfed upland cowpea. Field Crop Abstr 2001;54:359.

15. Pandian BJ, Anandakumar S, Veerabadran V, Ravichandran VK. Growth and yield of rice fallow green gram as influenced by method of sowing, stubble management and application in Tambiraparani command area. Madras Agric J 2001;88:406-9.

Cite this article: Kumar SRV, Suseendran K, Stalin P, Jawahar S, Arivukkarasu K. Graded Levels of NPK and Organic Sources of Nutrients on Productivity and Profitability of Fodder Maize. Asian J MultDisciplinary Res. 2019;5(1):8-11.

Source of Support: Nil, Conflict of Interest: None declared. 